\title{
Biodiversity Support and Ecotourism for Local Economic Development of Margasari Village - East Lampung District - Indonesia
}

\author{
Endang L. Widiastuti ${ }^{1,2,}{ }^{*}$, Henni W. Maharani ${ }^{1}$, Harnes Abrini ${ }^{2}$ \\ ${ }^{1}$ Coastal and Marine Research Center, Universitas Lampung, Jl. S. Brodjonegoro No. 1, Bandar \\ Lampung, Indonesia \\ ${ }^{2}$ Department of Biology, Universitas Lampung, Jl. S. Brodjonegoro No. 1, Bandar Lampung, Indonesia \\ *Corresponding author. Email: elwidi@yahoo.com
}

\begin{abstract}
Mangrove is known to be a greenbelt of the coast with its function not only for the physical and chemical processes along the coast line affected by sea-and fresh-water current but also functioning as habitat for many animals, including migratory birds. Mangrove in Margasari village or Lampung Mangrove Center (LMC) is dominated by Avicennia marina with density of 333 trees/ha, followed by Rhizophora mucronata with density of 467 trees/ha. Coastline of Lampung Province attracts for birds to migrate from asia to australia and vice versa. About 38 species of birds was found during field observation made on February - June 2018. Some of the birds found was considered to be endangered like a Great Knot (Calidris tenuirostris), some was threatened like Eurasian Curlew (Numenius arquata) and Chinnesse Egret (Egretta eulophotes). Not only birds, mangrove also provides some habitat for many different communities, such fishes, moluscs, crabs, and else in which they can be part of the ecotourism. Generating activities related to mangrove ecotourism provides economic for the locals such as, canoeing, fishing, seedling and culinary. Renting canoes by fishermen might help to generate some income (one canoe is rented for 200.000 rupiah/day). Fishing, for special tourism, in the mangrove which predominantly habitat for mud catfish is promising to generate some local income. Seedling of red mangrove (Rhizophora sp), can be introduced as part of eco-edutourism. Culinary is the most promising acts also to generate local economics, seafood and some other mangrove products can support the mangrove (LMC) ecotourism.
\end{abstract}

Keywords: Mangrove, biodiversity, economic development, ecotourism, Margasari, Lampung

\section{INTRODUCTION}

Lampung Province as one of the provinces in Indonesia's archipelago has 62 small islands with total of $250 \mathrm{~km}$ in coastal line. Four main rivers of Lampung Province end up in east coast of Lampung, making huge area of wetland, particularly mangrove area. It is well known that in 1970's clear cutting of mangrove had been vastly converted into shrimp and fish ponds, leaving the east coast of Lampung to be unprotected from any natural disasters, such as flooding of the river basin area and seawater intrusion. It was then in early 1990's some land of the previous mangrove area emerging and starting to grow as new area of mangrove with Avicenna as pioneer mangrove plants. It was not as simple as it was, this elevated property right of mangrove itself.

Even though from 2004 to 2013, the impact increased by $62 \%$ due rehabilitation by government, local villagers and University of
Lampung [1], yet some interest conflict in mangrove area still occur. As it already predicted that the success of mangrove rehabilitation also raised a potential conflict [2]. One of which, especially was in use of firewood for marginal communities around mangrove forest. Therefore, a study to determine the mangrove growth, potential, and methods of using eco-friendly for the public welfare is also needed. The aim of this study is to indicate any local potential benefits which may develop from the mangrove of Margasari Village of East Lampung District which is known as Lampung Mangrove Center (LMC).

\section{METHODS}

The study was conducted by desk study from site study references and direct observation on biodiversity of flora and fauna of the Lampung Mangrove Center and surrounding area. 


\section{RESULTS AND DISCUSSION}

\subsection{Biodiversity of Lampung Mangrove Center (LMC)}

Mangrove is known to be a greenbelt of the coast with its function not only for the physical and chemical processes along the coast line affected by sea-and fresh-water current but also functioning as habitat for many animals, including migratory birds.
The mangrove ecosystem of LMC is dominated by Avicennia marina with density of 333 trees/ha, followed by Rhizophora mucronata with density of 467 trees/ha. Beside these two mangrove plants, some other plants also can be found in LMC, such as Bruguirea spp, Sonneratia caseolaris, and other shrub which related to mangrove ecosystem (Table 1, Figure 1).

Table 1. Plant diversity and use of Lampung Mangrove Center

\begin{tabular}{|c|l|c|l|}
\hline No & \multicolumn{1}{|c|}{ Plant Name } & Density/ha & \multicolumn{1}{|c|}{ Local Uses } \\
\hline 1 & Avicennia marina & $333^{1}$ & Fire wood \& medicinal herb \\
\hline 2 & Avicennia officinalis & $1,791^{2}$ & Medicinal herb \\
\hline 3 & Rhizopora apiculata & $33^{2}$ & Medicinal herb \\
\hline 4 & Rhizopora stylosa & $467^{1}$ & Food \& Beverage \\
\hline 5 & Rhizopora mucronata & rare $^{3}$ & Fire wood \\
\hline 7 & Aegyceras spp & $12^{1}$ & Medicinal herb \\
\hline 8 & Sonneratia caseolaris & $357^{1}$ & $\begin{array}{c}\text { Spread throughout } \\
\text { water channel }\end{array}$ \\
\hline 9 & Acanthus ilicifolius & & \\
\hline
\end{tabular}

\section{${ }^{1}[3],{ }^{2}[4],{ }^{3}[5]$}

Lies between two continents, asia and australia, makes coastline of Lampung Province to be one of the areas which suitable for birds to migrate from asia to australia and vice versa. For about 38 different species from 14 different families (Tabel 2, Figure 2) was found in the LMC during observation made on May - June 2017.

This number was double than observation made by Kesuma [6]. It is expecting that the number will increase by thoroughly observation made throughout the full year.

Beside birds, some other fauna can be found such as fishes, crustaceans and amphibians. Some different invertebrates, such as molluscs and arthropods, can be easily found the LMC.

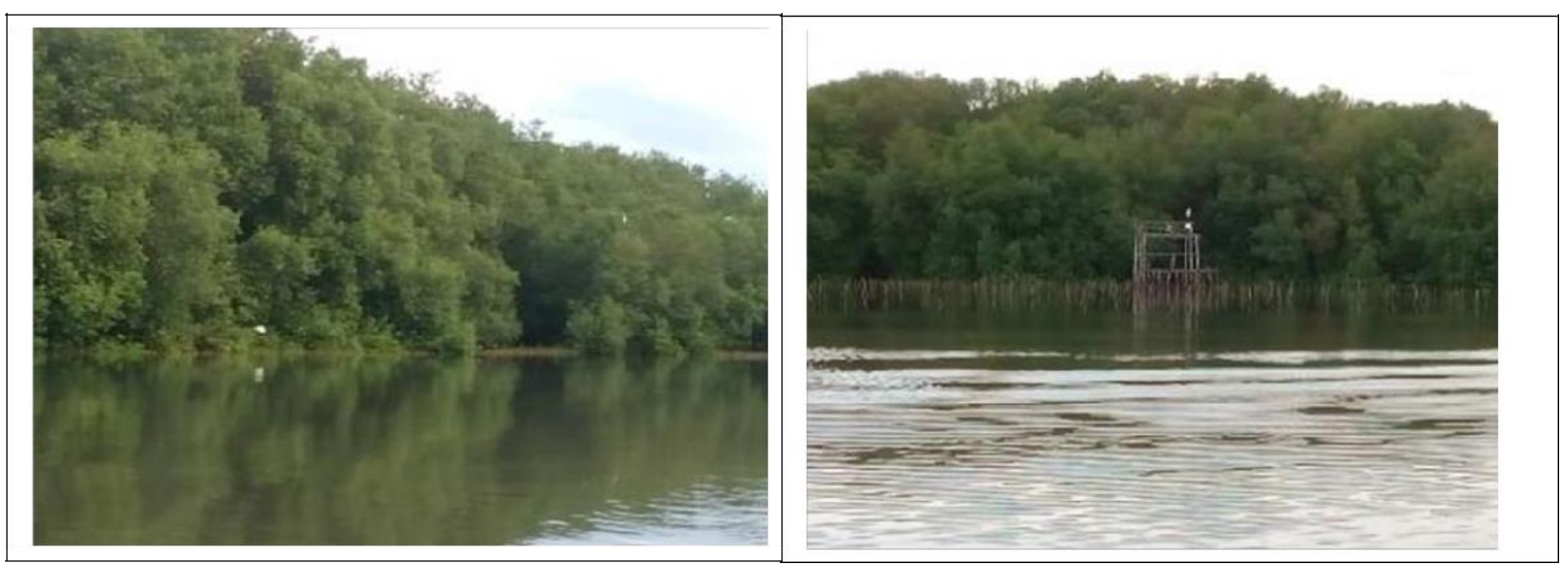

Figure 1. Mangrove ecosystem of LMC 


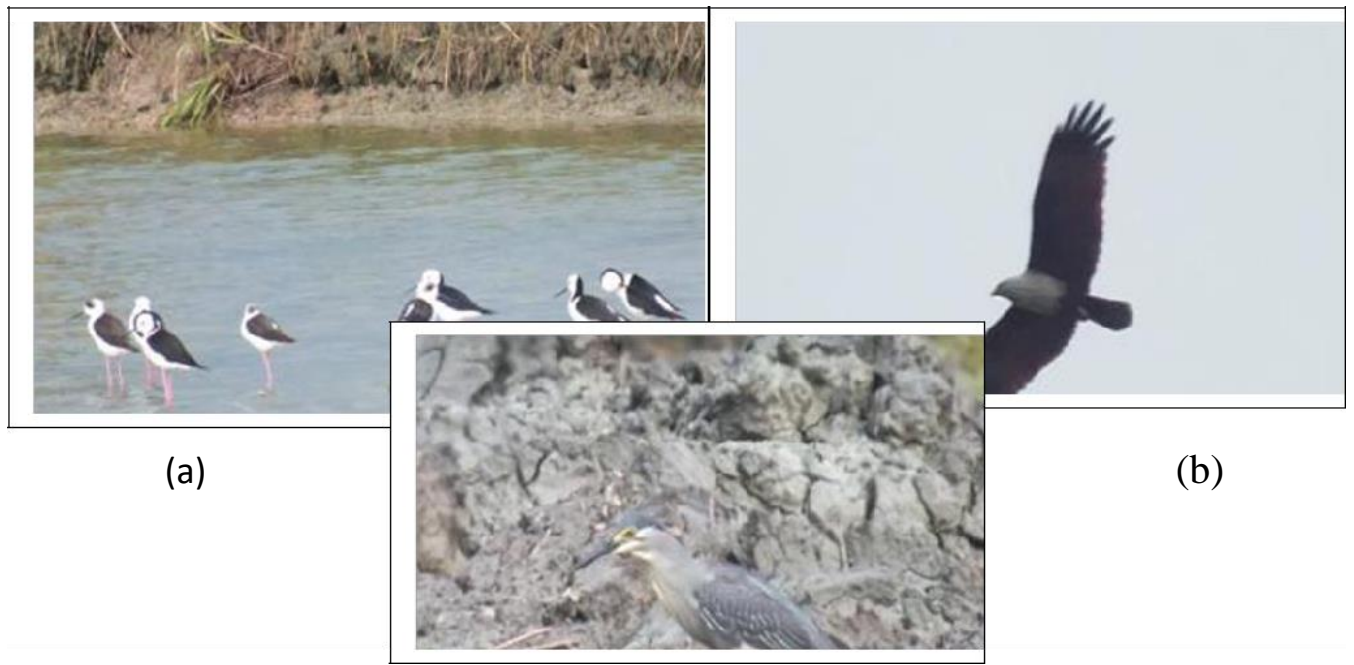

(c)

Figure 2. Some of birds found in LMC (a. Himantopus leucocephalus, b. Haliatus indus, c. Butorides streatus)

\subsection{Ecological Site of the LMC}

With its typical shallow coastal water, LMC was also suitable for canoeing activity (Figure 3). Time suitable for canoeing while watching birds is during early morning $(06.00-08.00 \mathrm{am})$ and late afternoon (15.00-17.00) when many birds can be found searching food and socializing among them. Pricing for canoeing could generate some income for the locals. For instance, mostly one canoe is rented for $200.000 \mathrm{IDR} / \mathrm{day}$. Yet, this income can be sustained by government through blue economy approach [7], such as building up community empowerment in mangrove resource monitoring and control, optimizing mangrove management and marketing and managing environment friendly fish/shrimp cultures surrounding the mangrove forest. Community empowerment also included with enhancing their knowledge over mangrove management and tourist marketing [8], [9], [10] as well as understanding on legislation and law enforcement on it [11].

Table 2. Bird diversity in Lampung Mangrove Center ${ }^{1}$

\begin{tabular}{llllr}
\hline No & \multicolumn{1}{c}{ Fam/Genus } & \multicolumn{1}{c}{ Common name } & \multicolumn{1}{c}{ Species } & IUCN \\
\hline 1 & Accipitridae & Brahminy Kite & Haliastur indus \\
2 & Accipitridae & Crested Serpent-eagle & Spilornis cheela & LC \\
3 & Alcedinidae & Small Blue Kingfisher & Alcedo coerulescens & LC \\
4 & Alcedinidae & White-throated Kingfisher & Halcyon smyrnensis & LC \\
5 & Alcedinidae & Collared Kingfisher & Todiramphus chloris & LC \\
6 & Ardeidae & Grey Heron & Ardea cinerea & LC \\
7 & Ardeidae & Purple Heron & Ardea purpurea & LC \\
8 & Ardeidae & Javan Pond-heron & Ardeola speciosa & LC \\
9 & Ardeidae & Cattle Egret & Bubulcus ibis & LC \\
10 & Ardeidae & Striated Heron & Butorides striata & LC \\
11 & Ardeidae & Great Egret & Ardea alba & LC \\
12 & Ardeidae & Chinese Egret & Egretta eulophotes & VU \\
13 & Ardeidae & Little Egret & Egretta garzetta & LC \\
14 & Ardeidae & Black-crowned Night-heron & Nycticorax nycticorax & LC \\
15 & Charadriidae & Kentish Plover & Charadrius alexandrinus & LC \\
16 & Charadriidae & Pacific Golden-plover & Pluvialis fulva & LC
\end{tabular}




\begin{tabular}{|c|c|c|c|c|}
\hline 17 & Estrildidae & Chestnut Munia & Lonchura atricapilla & LC \\
\hline 18 & Estrildidae & white-caped munia & Lonchura ferruginosa & LC \\
\hline 19 & Estrildidae & Scaly-breasted Munia & Lonchura punctulata & LC \\
\hline 20 & Hirundinidae & Asian House Martin & Delichon dasypus & LC \\
\hline 21 & Hirundinidae & Barn Swallow & Hirundo rustica & LC \\
\hline 22 & Hirundinidae & Tahiti Swallow & Hirundo tahitica & LC \\
\hline 23 & Laridae & Great Crested-Tern & Thalasseus bergii & LC \\
\hline 24 & Meropidae & Blue-tailed Bee-eater & Merops philippinus & $\mathrm{LC}$ \\
\hline 25 & Pandionidae & Osprey & Pandion haliaetus & $\mathrm{LC}$ \\
\hline 26 & Phalacrocoracidae & Little Black Cormorant & Phalacrocorax sulcirostris & LC \\
\hline 27 & Podicipedidae & Little Grebe & Tachybaptus ruficollis & LC \\
\hline 28 & Pycnonotidae & Sooty-headed Bulbul & Pycnonotus aurigaster & LC \\
\hline 29 & Recurvirostridae & White-headed Stilt & Himantopus leucocephalus & LC \\
\hline 30 & Scolopacidae & Great Knot & Calidris tenuirostris & EN \\
\hline 31 & Scolopacidae & Eurasian Curlew & Numenius arquata & NT \\
\hline 32 & Scolopacidae & Whimbrel & Numenius phaeopus & LC \\
\hline 33 & Scolopacidae & Common Sandpiper & Actitis hypoleucos & LC \\
\hline 34 & Sylviidae & Dark-necked Tailorbird & Orthotomus ruficeps & LC \\
\hline 35 & Threskiornithidae & Glossy Ibis & Plegadis falcinellus & LC \\
\hline 36 & Ploceidae & Eurasian Tree Sparrow & Passer montanus & LC \\
\hline 37 & Apodidae & Glossy Swiftlet & Collocalia esculenta & LC \\
\hline 38 & Apodidae & Black-nest Swiftlet & Aerodramus maximus & $\mathrm{LC}$ \\
\hline
\end{tabular}

${ }^{1}$ presented in national seminar 2018, *LC: least concern, VU: vulnerable, EN: endangered, NT: near threatened

\subsection{Local Economic Development}

Ecotourism, especially in mangrove, can be sustained by involving the locals for managing and providing some economic values to them, not only by generating some income but also providing job opportunities for the locals [12]. Therefore, empowering the locals, especially for local women would give great benefit for both the ecosystem itself as well as the managing mangrove ecotourism.

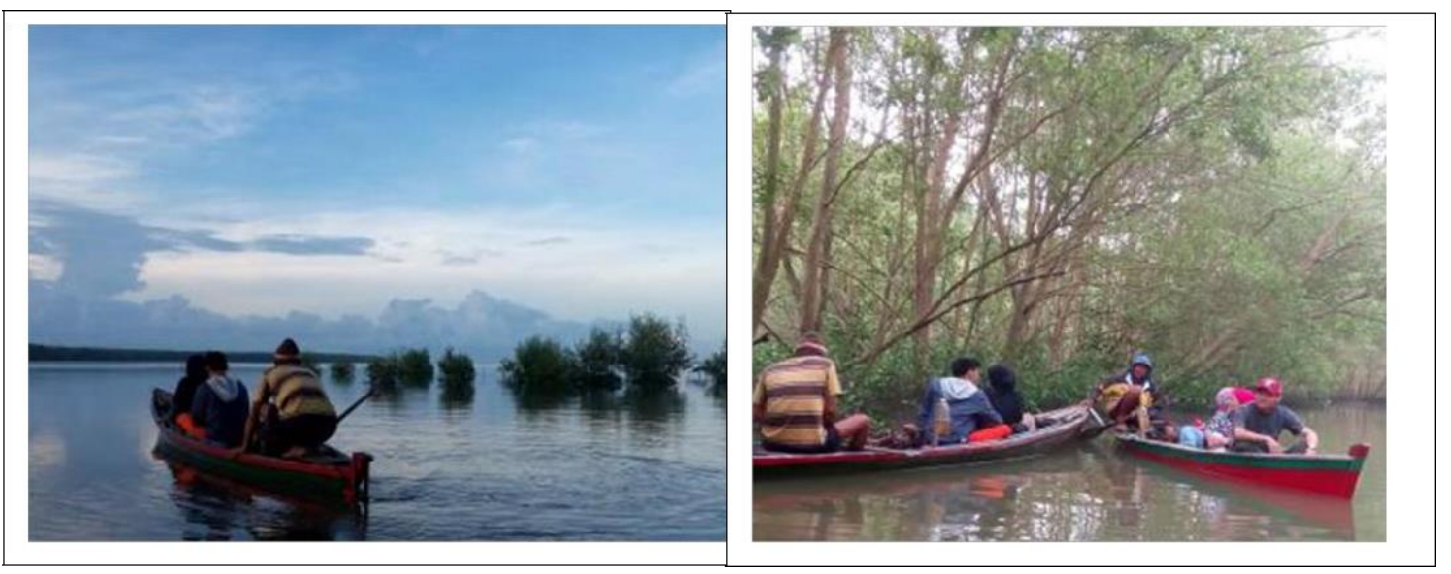

Figure 3. Typical shallow water of Lampung Mangrove Center of Margasari Village

A study also indicated that the total economic values of LMC reached up to 10 billion IDR a year [13], including obtained value from direct use for catching fish/crabs, production from mangrove apple (Sonneratia caseolaris) and holly mangrove (Acanthus ilicifolius) for snack and beverage, fire wood and ecotourism, which was accounted closely to $20 \%$ overall. Yet, this number seemingly superficial unless sustainable managing of LMC with surrounding fishery activity can be side by side.

As it had already mentioned, in order to conserve mangrove ecosystem, blue economic approach was also introduced by Bidayani [7], 
including developing fish/shrimp culture which side by side with mangrove conservation. However, putting the environment friendly fish/shrimp culture was not introduced into part of the eco-edutourism related to mangrove management. We are endorsing eco-edu-tourism to mangrove ecosystem of LMC in Margasari Village of East Lampung District with its adjacent fish/shrimp culture.

People are able to learn how the ecosystem supported the fish/shrimp culture while they also learn how to manage the culture which site by site with surrounding ecosystem.

Improving ecotourism in LMC by introducing eco-edu-tourism, therefore, is necessary to be done. Some tourism activities related to it, such as:

1. Enhancing Mangrove Ecosystem by providing how to do mangrove plant nursing, seedling and planting,

2. Conducting education for eco-sound shrimp culture,

3. Presenting how to use mangrove products (seed, fruit and leaves) for snack such as chips, cookies and beverage,

4. Introducing Phyto pharmacy that can be generated by using mangrove products (seed, fruit and leaves),

5. Introducing crab culture which can provide culinary tourism.

\section{CONCLUSIONS}

We can conclude that generating some tourism activities related to existing mangrove in LMC such as, canoeing, fishing, seedling and culinary may affect local incomes from which then the supports to mangrove conservation as migratory bird habitat can be provided by the local people.

\section{REFERENCES}

[1] Yuliasama, A. Darmawan, R. Hilmanto, Perubahan Tutupan Hutan Mangrove di Pesisir Kabupaten Lampung Timur. Jurnal Silva Lestari Vol. 2 No. 3: 2014, pp. 111-124

[2] A. Kustanti, B. Nugroho, C. Kusmana, D. Darusman, D. Nurrochmat, M. Krott, C. Schusser, Actor, Interest and Conflict in Sustainable Mangrove Forest Management A Case from Indonesia. Int. Jornal of Marine Science Vol. 4 No. 16: 2014, pp. 150-159.

[3] Universitas Lampung, Master Plan Rehabilitasi Hutan Mangrove Pesisir Timur Provinsi Lampung. 2007.
[4] I. Supriyanto, and A. Bintoro, Medicinal Plant Species Inventory on Mangrove Forest at Margasari Village, Labuhan Maringgai District, East Lampung. Jurnal Silva Lestari Vol. 2 No. 1: 2014, pp. 67-76.

[5] E.L. Rusita, G.J. Rustiati, Winarno, B.S. Dewi, C. Windarni, Kajian Potensi Hutan Mangrove Di Lampung Mangrove Center (LMC) Untuk Pengembangan Ekowisata Berbasis Masyarakat. Jurnal Hutan Pulau Pulau Kecil Vol. 1 (2): 2016, pp. 84-91.

[6] M.I. Kesuma, B.S. Dewi, N. Nurcahyani, Keanekaragaman Jenis Burung di Lampung Mangroce Center Desa Margasari Kecamatan Labuhan Maringgai Kabupaten Lampung Timur. Prosiding Seminar Nasional Sains dan Teknologi V. Lembaga Penelitian Universitas Lampung. 19-20 November 2013.

[7] E. Bidayani, Soemarno, N. Harahap, Rudianto, Blue Economic Approach-Based Mangrove Resources Conservation for Coastal Community's Prosperity in Sidoarjo Regency, East Java, Indonesia. International Journal of Ecosystem 6(1): 2016, pp. 1-9.

[8] Nuriawati, B. Siswoyo, L. Wardana, Development Strategy of Mangrove Conservation and Ecotourism Beejay Bakau Resort. IOSR Journal of Business and Management Vol. 18: Issue 5: 2016, pp. 116122.

[9] H. Idajati, A. Pamungkas, S.V. Kukinul, The level of participation in Mangrove ecotourism development, Wonorejo Surabaya. ProcediaSocial and Behavioral Sciences 227:2016, pp. 515-520.

[10] T.R.O. Hewlett, Benefit or Empty Promises: Ecotourism and Local Communities. 2011. Proceedings of North-eastern Recreation Research Symposium.

[11] D. Arkwright, and I.S. Kaomaneng, Mangrove Ecotourism Development on Kakaralamo Island Nort Halmahera: Community perception, participation and development strategies. 2018 IOP Conf. Ser.: Earth Environ. Sci. 175012232.

[12] R.O.P. Situmorang, Social Capital in Managing Mangrove Ecotourism Area by The Muara Baimbai Community. Indonesian Journal of Forestry Research Vo. 5. No. $1: 2018$, pp. 21-34.

[13] R.I. Ariftia, Q. Rommy, H. Susni, Total Economic Value of Mangrove Forest in Margasari, Labuhan Maringgai District, Lampung Timur Regency. Jurnal Silva Lestari Vol. 2. No. 3: 12014, pp. 9-2. 